\title{
Agricultural Vulnerability and Adaptation to Climatic Changes in Malaysia: Review on Paddy Sector
}

\author{
Md. Mahmudul Alam* \\ PhD Candidate \\ Institute for Environment and Development (LESTARI) \\ National University of Malaysia (UKM), Malaysia \\ E-mail: rony000@gmail.com \\ Chamhuri Siwar \\ Emeritus Professor \\ Institute for Environment and Development (LESTARI) \\ National University of Malaysia (UKM), Malaysia \\ E-mail: csiwar@ukm.my \\ Abdul Hamid Jaafar \\ Professor \\ Faculty of Economics and Management \\ National University of Malaysia (UKM), Malaysia \\ E-mail: ahamid@ukm.my \\ Basri Talib \\ Associate Professor \\ Faculty of Economics and Management \\ National University of Malaysia (UKM), Malaysia \\ E-mail: basri@ukm.my \\ Khairulmaini Bin Osman Salleh \\ Professor and Head of Department \\ Department of Geography \\ University of Malaya, Malaysia. \\ Email: khairulmaini@gmail.com \\ *corresponding author
}

\section{Citation Reference:}

Alam, M.M., Siwar, C., Jaafar, A.H., Talib, B., and Salleh, K.O. 2013. Agricultural Vulnerability and Adaptation to Climatic Changes in Malaysia: Review on Paddy Sector. Current World Environment, 8(1): 1-12. [Online Link]

This is a pre-publication copy.

The published article is copyrighted by the publisher of the journal. 


\title{
Agricultural Vulnerability and Adaptation to Climatic Changes in Malaysia: Review on Paddy Sector
}

\begin{abstract}
Climate change has mixed impacts on agriculture and the impacts are different in terms of areas, periods and crops. The changing factors of climate have been exerting strong negative impacts on Malaysian agriculture, which is apprehended to result in shortages of water and other resources for long term, worsening soil condition, disease and pest outbreaks on crops and livestock, sea-level rise, and so on. Due to climate change, agricultural productivity and profitability is declining. Despite continuous increases of government subsidy, area of paddy plantation is decreasing and the adaption practices are ineffective. As climate change is universal and its existence is indefinite, the farmers need to adapt to and find ways to mitigate the damages of climatic variation in order to sustain agricultural productivity and attain food security for them.
\end{abstract}

Key words: Climate Change, Agriculture, Food Security, Sustainability, Adaptation, Mitigation, Vulnerability, Malaysia.

\section{INTRODUCTION}

The changing patterns of climate factors adversely affect the social, economic and environmental agents all over the world. The agriculture is fully dependent on the factors of climate and consequences of climate change are of adverse impacts on agriculture and agriculture relevant stakeholders. Among all the stakeholders, farmer community is the most affected and risk group due to their full dependency on agriculture.

The climatic factors as expressed by the amount of rainfall, sunshine hours, temperature, relative humidity and length of the drought period result in year-to-year and area-to-area variability of crop production. Variability of production unit causes indirect impacts on the social and economic status of the livelihood of farming community along with several direct impacts- e.g. health hazards, frequent sickness etc.

The impacts of climate change are not limited to any geographical boundary or timeframe. Some of the aspects are long term and related to national or international security such as, soil erosion, chemical poisoning or nuclear waste (Daly and Cobb, 1990), and some issues are related to daily quality of life such as, water pollution, shortage of food or resources (Homer-Dixon, 1992; Alam et al., 2011d). The combined effects of these issues are difficult to predict such as, natural and environmental catastrophes in recent times- floods, landslides, long periods of drought etc (United Nations, 1997), and these cause vulnerability in terms of yield, farm profitability, regional economy and hunger (Reilly, 1999; Schimmelpfenning et al., 1996; Siwer et al., 2009).

Several impacts of climate change affect various sectors, regions and factors in different ways (Klein et al., 2005). Agricultural sector dominates the economies of $25 \%$ of the world's countries, where half of the world's workforce is currently employed. Due to the climate change the agricultural sector is vulnerable in terms of productivity and economic 
benefits. This paper provides a brief review on the global and Malaysian perspective of climate change, and its impacts on Malaysian agriculture and relevant adaptation practices, and policy recommendations for better coping with the changing nature of climatic factors.

\section{GLOBAL SCENARIO OF CLIMATE CHANGE}

Due to increasing atmospheric concentration of carbon dioxide and other trace gases, since the beginning of the 1980s, many climatologists predicted significant global warming in the coming decades. The Intergovernmental Panel on Climate Change (IPCC) was established in 1988 by the United Nations Environmental Programme (UNEP) and the World Meteorological Organization (WMO) to assess the scientific, technical and socioeconomic information relevant for the understanding of human induced climate change, its potential impacts and options for mitigation and adaptation.

National Academy of Science (2001) found trends of increasing average temperature and more volatile rainfall patterns. IPCC report 2007 shows further scientific evidence that the world's climate systems are changing faster than predicted, raising the likelihood of more rapid and damaging changes. It also motions 90-95\% likelihood that changes in modern climate have been caused by human actions (Figure 1).

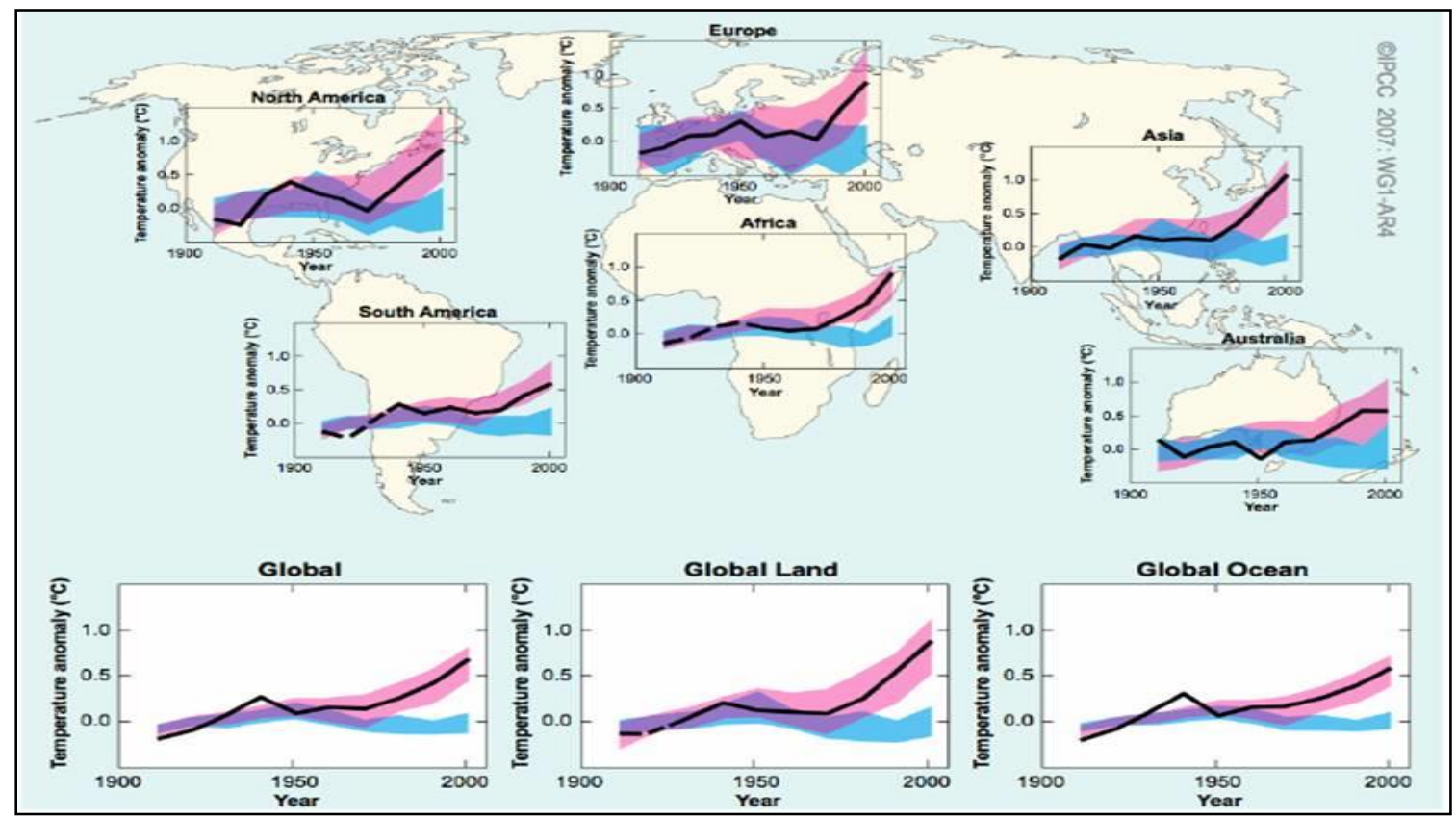

Figure 1: Regional and Global Climate change from 1990 to 2000

Source: IPCC 2007

According to the Third Assessment Report of IPCC (2001), if the levels of emissions are not reduced, the global average temperature will increase by $1.4^{\circ} \mathrm{C}$ to $5.8^{\circ} \mathrm{C}$ between 1990 and 2100. Another projection pointed to an increase in the average global temperature of $2.4^{\circ} \mathrm{C}$ between 1990 and 2100 , with $95 \%$ chance that the change will be between $1.0^{\circ} \mathrm{C}$ and $4.9^{\circ} \mathrm{C}$ (Webster et al., 2002). Other studies have estimated that the average global temperature is likely to rise by between $0.3^{\circ} \mathrm{C}$ and $1.3^{\circ} \mathrm{C}$ during the next 30 years (Zwiers, 2002). 
The warming to a great extent, during the next 30 years, will be due to emissions that have already occurred. Over the longer term, the degree and pace of warming depends mainly on current and near future emissions. There is more than $50 \%$ chance that in the longer term the temperature rise would exceed $5^{\circ} \mathrm{C}$. Due to the climate change impacts, the amount of $5 \%$ of the global GDP, which is regionally going up to even $20 \%$, is expected to amount at annual loss in future (Stern, 2007: iv).

Different behaviors of climate factors were found by different studies based on place and time differences. Average precipitation is expected to increase globally (IPCC, 2001), but the magnitude of regional precipitation changes as well as varies among models: with the range $0-50 \%$ where the direction of change is strongly indicated, and around -30 to $+30 \%$ where it is not. For some areas, it shows a positive trend in the daily intensity and a tendency toward higher frequencies of extreme rainfall in the last few decades (Houghton et al., 1996). Among them, the main areas where significant positive trends have been observed are USA (Karl et al., 1995; Trenberth, 1998; Kunkel et al., 1999), eastern and north-eastern Australia (Suppiah and Hennessey, 1998; Plummer et al., 1999), South Africa (Mason et al., 1999), UK (Osborn et al., 2000), and northern and central Italy (Brunetti et al., 2000, 2001).

Fuhrer et al. (2006) reviewed on Europe that both rain-day frequency and intensity during winter increases to the north (about $45^{\circ} \mathrm{N}$ ), while the rain-day frequency decreases to the south. This is also consistent with increases of mean winter precipitation by 10 to $30 \%$ over most of the central and northern Europe, and decreases over the Mediterranean. In summer, the most notable change is strong decreases in the frequency of wet days, for instance to about half in the Mediterranean, along with a 20 to $50 \%$ decrease of mean summer precipitation. In the tropics, models show an increase in Africa, a small increase in South America, but no change in Southeast Asia. Summer precipitation is expected to decrease in the Mediterranean-basin and in regions of Central America and north-western Europe. Bonaccorso et al. (2005) analyzed the trends of annual maximum rainfall series of Mediterranean areas and found different behavior patterns based on the different time scales, particularly shorter duration series shows increasing trends and longer duration series shows decreasing trends. In most cases when there is a positive trend in rainfall intensity, an increase in total precipitation has also been observed (Groisman et al., 1999). However this relationship is not universal. Observation shows that there is an increase in heavy precipitation in some areas (i. e. Italy) with a tendency toward a decrease in total precipitation (Brunetti et al., 2001).

The costs costs due to impacts of climate change have already been tried to point out by different institutions (WBGU 2003: 17; Stern 2007: iv). The joint research centre PESETA of the EC has calculated the costs in 1995 arising from sea level rise with and without adaptation measures by 2020 and 2080 (Commission of the European Communities, 2007: 10). Oxfam estimates that adaptation in developing countries will cost at least USD $\$ 50-\$ 80$ billion each year, based on the estimation from the World Bank, Stern and IPCC (Raworth, 2007). The costs of adapting existing urban water infrastructure in Africa alone have been estimated at USD \$1.05-\$2.65 billion annually, excluding the cost of rehabilitating deficient infrastructure. In Africa, the costs of climate-proofing new development are also likely to rise by USD $\$ 1-\$ 2.55$ billion a year (Muller, 2007).

The IPCC mentioned Africa as one of the most continents vulnerable to climate change (Boko et al., 2007). Very few parts of Africa will be benefited from a rising 
temperature, unlike some parts of the northern hemisphere (Canada, Japan, Russia). The UN Framework Convention on Climate Change (UNFCCC) identifies a list of 49 Least Developed Countries (LDCs), which are at high risk from climate change, and out of these countries at stake, 33 are located in Africa. A study analyzed that due to climate change, Southern Africa will lose more than $30 \%$ of its main crop, maize, by 2030, and Asia, especially South Asia and South East Asia will lose top 10\% of many regional staples, such as rice, millet and maize (Lobell et al., 2008)

All of the projections of the future climate change are based on the extrapolation of current trends with logical assumptions about future emissions of greenhouse gases, prospective economic and industrial growth, population growth, technological progress etc., which are not phenomenon for any particular country, rather they are global concern.

\section{CLIMATE CHANGE IN MALAYSIA}

According to the United Nations Development Report, carbon dioxide emissions in Malaysia increased by $221 \%$ during the period of 1990 to 2004, and the country is included in the list of 30 biggest greenhouse gas emitters. Curb Global Warming (2007) quoted from the Associated Press (AP) that rapid growth in emissions has occurred even though Malaysia ratified the Kyoto Protocol and has taken several initiatives to use renewable energy as well as ways to cut emissions. Currently Malaysia ranks as the $26^{\text {th }}$ largest greenhouse gas emitter in the world with a population of about 27 million, and it appears likely to move up the list quickly due to the growth rate of emissions.

Due to high greenhouse gas emissions, the temperature is projected to rise by $0.3^{\circ} \mathrm{C}$ to $4.5^{\circ} \mathrm{C}$. Warmer temperature will cause a rise in sea level about $95 \mathrm{~cm}$ over hundred periods. The changes in rainfall may fluctuate from about $-30 \%$ to $+30 \%$. This change will reduce crop yield and and will cause drought in many areas with a consequence that cultivation of some crops such as rubber, oil palm and cocoa will not be possible (MOSTE, 2001). Table 1 shows the projection of positive rainfall changes by 2050 in few areas of Malaysia. The projection shows maximum monthly precipitation will increase up to $51 \%$ in Pahang, Kelantan and Terengganu, while minimum precipitation decreases between $32 \%$ to $61 \%$ for all over Peninsular Malaysia. Consequently, annual rainfall will increase up to $10 \%$ in Kelantan, Terengganu, Pahang and North West Coast, and decrease up to 5\% in Selangor and Johor (NAHRIM, 2006). This variation of climate factors will make the agricultural system vulnerable in Malaysia.

Table 1: Future Rainfall and Temperature Change Projections in Peninsular Malaysia by 2050

\begin{tabular}{|c|c|c|}
\hline Area & \multicolumn{2}{|c|}{$\begin{array}{c}\text { Projected Change* in Maximum Monthly } \\
\text { Value }\end{array}$} \\
\hline Regions/Sub-regions/states & Temperature $\left({ }^{0} \mathrm{C}\right)$ & Rainfall (\%) \\
\hline $\begin{array}{l}\text { North East Region -Terengganu, Kelantan, Northeast- } \\
\text { coast }\end{array}$ & +1.88 & +32.8 \\
\hline North West Region-Perlis (west coast), Perak, Kedah & +1.80 & +6.2 \\
\hline Central Region-Klang, Selangor, Pahang & +1.38 & +8.0 \\
\hline Southern Region-Johor, Southern Peninsula & +1.74 & +2.9 \\
\hline
\end{tabular}

* Difference $=$ Average 2025-2034 \& 2041-2050 minus Average 1984-1993

Source: NAHRIM, 2006 


\section{CLIMATE CHANGE AND MALAYSIAN AGRICULTURE}

The global effect of climate change on agricultural production is minimum to moderate, where regional impacts are significant for many areas. Regional variations in gains and losses result in a slight overall changes in world cereal grain productivity.

Some studies addressed climate change impacts on rice yields, which vary greatly, in South and Southeast Asia (Matthews et al., 1994a, 1994b). Climatic impacts on agriculture span a wide range depending on the climate scenario, geographical scope, and study. While large changes were predicted for China, to a certain extent warming would be beneficial with yield increasing due to diversification of cropping systems. In case of Japan, the positive effects of $\mathrm{CO}_{2}$ on rice yields would be generally more than offset any negative climatic effects (MOSTE, 2001).

Under current climate change scenario, temperature above $25^{\circ} \mathrm{C}$ may decline grain mass of $4.4 \%$ per $1{ }^{\circ} \mathrm{C}$ rise (Tashiro and Wardlaw, 1989), and grain yield may decline as much as $9.6 \%-10.0 \%$ per $1{ }^{\circ} \mathrm{C}$ rise (Baker and Allen, 1993), where average temperature in rice growing areas in Malaysia is about $26^{\circ} \mathrm{C}$. Singh et al. (1996) mentioned that the actual farm yields of rice in Malaysia vary from 3-5 tons per hectare, where potential yield is 7.2 tons. It also mentioned that a decline of rice yield between $4.6 \%-6.1 \%$ per $1{ }^{\circ} \mathrm{C}$ temperature increases under the present $\mathrm{CO}_{2}$ level, but a doubling of $\mathrm{CO}_{2}$ concentration (from present level 340ppm to $680 \mathrm{ppm}$ ) may offset the detrimental effect of $4^{\circ} \mathrm{C}$ temperature increase on rice production in Malaysia. In a recent study it is found that a $1 \%$ increase in temperature leads to a $3.44 \%$ decrease in current paddy yield and $0.03 \%$ decrease in paddy yield in next season; and a $1 \%$ increase in rainfall leads to $0.12 \%$ decrease in current paddy yield and $0.21 \%$ decrease of paddy yield in next season (Alam et al., 2010a).

Tisdell (1996) mentioned that rainfall variability increases the level of environmental stress that affects the capability of the system to maintain productivity. The projection of paddy yield in the country shows that any positive or negative variation of above $0.4 \%$ in both rainfall and temperature will decrease the yield of paddy production by 2020 (Table 2). When considering a positive or negative variation of above $0.7 \%$ in both rainfall and temperature by 2040, paddy yield tends to decline further and this negative trend of paddy yield is expected to continue by the year 2060, considering the variation $( \pm)$ of above $1 \%$. These clearly indicate a very high level of vulnerability of paddy productivity due to the climatic variation in the next couple of decades. This indicates that climate change has an adverse impact on agriculture in Malaysia.

Table 2: Projection of Paddy Yield (Kg/Ha) with Different Variations of Temperature and Rainfall at Certain Level of $\mathrm{CO}_{2}$

\begin{tabular}{|c|c|c|c|c|c|c|c|c|c|c|c|}
\hline \multicolumn{4}{|c|}{ Year 2020* } & \multicolumn{4}{|c|}{ Year $2040^{\wedge}$} & \multicolumn{4}{|c|}{ Year 2060 } \\
\hline \multirow{2}{*}{$\begin{array}{l}\text { Variation } \\
\text { in } \\
\text { Rainfall }\end{array}$} & \multicolumn{3}{|c|}{$\begin{array}{c}\text { Variation in } \\
\text { Temperature }\left({ }^{0} \mathrm{C}\right)\end{array}$} & \multirow{2}{*}{$\begin{array}{c}\text { Variation } \\
\text { in } \\
\text { Rainfall }\end{array}$} & \multicolumn{3}{|c|}{$\begin{array}{c}\text { Variation in } \\
\text { Temperature }\left({ }^{0} \mathrm{C}\right)\end{array}$} & \multirow{2}{*}{$\begin{array}{c}\text { Variation } \\
\text { in } \\
\text { Rainfall }\end{array}$} & \multicolumn{3}{|c|}{$\begin{array}{c}\text { Variation in } \\
\text { Temperature }\left({ }^{\circ} \mathrm{C}\right)\end{array}$} \\
\hline & 0.3 & 0.85 & 1.4 & & 0.4 & 1.4 & 2.4 & & 0.6 & 2 & 3.4 \\
\hline$\%$ & 6,156 & 5,806 & 5,586 & $23 \%$ & 7,342 & 6,9 & 6,542 & 32 & 8,619 & 8,059 & 7,4 \\
\hline 10 & 6,646 & 6,306 & 6,086 & $11 \%$ & 8,200 & 7,800 & 7,400 & 10 & 9,834 & 9,274 & 8,714 \\
\hline $.4 \%$ & 7,202 & 6,862 & 6,642 & $0.7 \%$ & 9,042 & 8,642 & 8,242 & $1 \%$ & 10,962 & 10,402 & 9,842 \\
\hline$\%$ & 7,202 & 6,862 & 6,642 & $0 \%$ & 9,042 & 8,642 & 8,242 & $0 \%$ & 10,962 & 10,402 & 9,642 \\
\hline
\end{tabular}




\begin{tabular}{|llll|llll|lrl|l|}
$0.4 \%$ & 7,202 & 6,862 & 6,642 & $-0.7 \%$ & 9,042 & 8,642 & 8,242 & $-1 \%$ & 10,962 & 10,402 & 9,642 \\
$-7 \%$ & 6,698 & 6,382 & 6,177 & $-11 \%$ & 8,047 & 7,691 & 7,335 & $-15 \%$ & 9,318 & 8,842 & 8,366 \\
$-14 \%$ & 6,194 & 5,901 & 5,712 & $-23 \%$ & 6,962 & 6,654 & 6,346 & $-32 \%$ & 7,454 & 7,073 & 6,693 \\
\hline
\end{tabular}

Source: MOSTE (2001)

Alam et al. (2011a) indicate that the yearly total rainfall is increasing and its monthly variation is too high. The adverse effects of lower rainfall can be reduced or averted by introducing proper irrigation system. But the effect of the opposite phenomenon of over rainfall especially at the end of the crop cycle or at the maturity period is absolutely uncontrollable.

The climatic change causes change in several agriculture relevant factors that determine the sustainability of agricultural production. Farmers believe that vulnerability of some of the factors like injurious insects (supported by $42.9 \%$ of the farmers), temperature (supports by $58.6 \%$ of the farmers), soil fertility loss (supports by $49.5 \%$ of the farmers), cost of inputs (supports by $61.1 \%$ of the farmers), shortage of rainfall (supports by $45.5 \%$ of the farmers), excessive rainfall (supports by $35.9 \%$ farmers) increased over the last 5 years (Alam et al., 2011b). Due to the climate change impacts on agriculture, the projections of NAHRIM of paddy yield in terms of climate change, in a given level of temperature and $\mathrm{CO}_{2}$ level, shows more than $0.4 \%$ variation of rainfall by 2020 and will cause a fall in paddy yield in Malaysia (NAHRIM 2006). Therefore the agricultural sustainability in the future in Malaysia is projected to be vulnerable due to climatic changes.

\section{AGRICULTURAL ADAPTATION}

Farmers' adaptation practices to cope with the agricultural vulnerability due to climatic change are not found adequate and satisfactory (Alam et al., 2011c, 2012a,c). Their adaptation methods are based only on their ideas or reactions. As a result, only $30.3 \%$ farmers believe that they have been able to properly cope with climatic vulnerabilities (Alam et al., 2012d).

On the issue of availability of external supports, most of the farmers were not found aware of the current supports provided by external parties to adapt to climate change. But, in order to support the farmers to increase productivity and increase income, government's subsidy for agricultural sector is increasing each year (Table 3). Worth noting to mention that government of Malaysia currently provides huge amount of subsidy to the paddy producers to encourage paddy cultivation and to ensure more production for increasing the country's selfsufficiency level. The types and contents of these subsidies have been summarized below:

- Input subsidy: 12 beg (20 kg each) compound fertilizer and 4 beg (20kg each) urea fertilizer per hectare - worth MYR 400 and pesticide incentive MYR 200 per hectare.

- Price Subsidy: Provided at the selling price - MYR 248.1 per ton.

- Rice Production Incentive: Land preparation/plowing incentive - MYR 100 per hectare and organic fertilizer 100kg per hectare - worth MYR 140.

- Yield Increase Incentive: Provided if producers (farmers) are able to produce 10 tons or more per hectare - MYR 650 per ton.

- Free Supports: Free supports for irrigation, infrastructure, and water supply. 
Table 3: Government Subsidy (in MYR) for Paddy Sector in Malaysia

\begin{tabular}{lcccr}
\hline \multicolumn{1}{c}{ Items } & 2004 & 2005 & 2006 & \multicolumn{1}{c}{2007} \\
\hline \hline Subsidy For Paddy Price & $476,628,303$ & $443,218,042$ & $445,749,898$ & $444,000,000$ \\
Paddy Fertilizers & $186,744,867$ & $178,072,073$ & $396,393,001$ & $261,677,743$ \\
Paddy Production Incentive & NA & NA & NA & $67,563,904$ \\
Yield Increase Incentive & NA & NA & NA & $85,434,620$ \\
Paddy Seed Help & NA & NA & NA & $17,000,000$ \\
Diesel Subsidy Scheme & NA & NA & $989,727,418$ & $1,099,000,723$ \\
Petrol & NA & NA & $45,413,959$ & $69,461,384$ \\
\hline Total Subsidy and Incentive & $663,373,170$ & $621,290,115$ & $1,877,284,276$ & $2,044,138,374$ \\
\hline
\end{tabular}

Note: NA means data were not found available.

Source: Agriculture Statistical Handbook, 2008

The subsidies for urea and compound fertilizer have been continuing since 1979. The incentive for land preparation and using organic fertilizer has been continuing since 2007. Providing urea and compound fertilizer and pesticide incentive was introduced in 2008 and these supports are still continuing. Still farmers expect several types of external supports to cope properly with the changes in climatic factors. Among several types of expected new supports, farmers significantly believe moisture deficiency related innovations, crop development, cash incentive, infrastructural supports, and adjustment in wage, and leasing system are required to adapt to climate change (Alam et al., 2012a).

\section{POLICY RECOMMENDATION AND CONCLUSIONS}

As climate change is a continuous and long term process, its effects and solutions are similarly time and effort consuming process. Most of the warming during the next 30 years will be due to emissions that have already occurred. Over the longer term, the degree and pace of warming mainly depend on current and near future emissions (Stern, 2007). To adapt with climate change, conventionally, mitigation has received more attention than adaptation, both from a scientific and policy perspectives. Mitigation is the main way to prevent future impacts of climate change, and it will reduce the cost of adaptation. So, any delay in mitigation strategy to reduce emissions will increase the need and cost of adaptation, and increase the risk of being victim of global climate change. On the other hand, though adaptation is not a substitute of mitigation, there are arguments for adaptation to consider as a response measure. Mitigation actions never stop a certain degree of climate change due to historical emissions and the inertia of the climate system (IPCC, 2001). Moreover, mitigation effects may take several decades to manifest, where most adaptation activities take immediate effects. Adaptation reduces risks associated with current climate variability as well as addressing the risks associated with future climate changes, where mitigation only focuses on future risks. The measures of adaptation can be applied to a local scale or root level with the involvement of large number of stakeholders, where mitigation works in the decision making level. In the current world, climate factors are exogenous variables that are immitigable in a quick manner and as a consequence adaptation is the most appropriate way to cope with the system properly. It is therefore important to strike a balance between measures against the causes of climate change and measures to cope with its adverse effects (Stern, 2007; Pielke et al., 2007).

In recent years, adaptation has gained prominence as an essential response measure, especially for vulnerable countries due to the fact that some impacts are now unavoidable in 
the short to medium term. Mitigation is necessary but adapting to future risk is more important. Immediate and long term actions are essential for various factors including government, development partners, research organizations, and community organizations. In fact, adaptation is too broad to attribute its costs clearly, because it needs to be undertaken at many levels, including at the household and community level, and many of these initiatives are self-funded (Stern, 2007). Options for agricultural adaptation can be grouped as technological developments, government programs, farm production practices, and farm financial management (Smith, 2002). So, it has been suggested to prepare a planned and proactive adaptation strategy to secure sound functioning of the economic, social and environmental system.

Government as the policy and law making authority has to play the most influential role to ensure climatic mitigation and adaptation at all levels (Alam et al., 2010b, 2012b). It is the main responsibility of government to give enough supports in order to enable farmers to adapt to different climatic situations and to make them self-sufficient rather than subsidy dependent. Appropriate authorities also need to carefully define government's subsidy supports and incentive programmes to influence farm-level production, practices, and financial management. Hence, agricultural policies and investments need to be more strategic. But the government needs to define and ensure the compensation, minimum income protection, and insurance facility for the affected groups - individual farmer or farm. In the planning processes, policy makers need to account the barriers of adaptation including ecological, financial, institutional, and technological barriers, as well as information and cognitive hurdles. Other few important issues need to be focused, such as stakeholders may not sufficiently inform about the needs and possible strategies of climate change (Eisenack et al., 2006, 2007), farm level faces uncertain future and hinders the development process, causes obstacle for implementation of adaptations policy (Behringer et al., 2000; Brown et al., 2007), and the policy deals with different conflicting interest groups. To avoid the negative impacts of climate changes on agriculture and to control pollutions and emissions in the sector, however, proper mitigation policies are urgently required for Malaysia. Further, Malaysian agriculture sector also needs to include mitigation policies due to the emission of commercial farming.

The issues of mitigation and adaptation to climate change concern all sectors as well as all levels of political, administrative, economic and everyday life. To better cope up, cooperation is necessary across countries, sectors and administrative levels. Relevant agencies need to be aware of the benefits of cooperation to gain long-term benefits instead of focusing only on short-term and individual interest. The production practices of farm and the knowledge of individual farmer also need to be updated with the changes of climate factors. The agricultural farmers should understand the crop rotation, crop portfolio, and crop substitutions. They should also take all precautions and be aware about the uncertainty of low rainfall and heavy rainfall. The financial management of agricultural farms must be efficient and the farmers must secure minimum two cropping seasons so that if crops damage in one season they will have the seeds for next season. This will help them bear the cost of another crop production and survive financially up to the time when new crops are collected. But this will make the farmers take initiative for crop sharing, forward rating, hedging, and insurance etc.

Different new groups of stakeholders also need to be engaged to ensure necessary facilities for the farmers. Financial institutions also need to be engaged more inclusively in 
order to provide supports of loan, insurance, saving schemes, hedging or future option, and so on to the agricultural farmers. Technological adaptation to climate change is also important to deal with the climatic problems in the long run. It is apparent that development of technology is a boundless area, but it is possible in several ways. The highest efficient method of technological advancement is expected to be able to solve the problem. Until gaining such level of technological advancement, there should be some alternative options which are expected to help the agricultural farmers in their effort to adapt to climate changes in the following ways:

- To solve the problem: controlling the pattern of rainfall, sunshine, and moisture level.

- To improve shielding resources: protecting crops from excessive rainfall or sunshine and solving water logging problems.

- To develop defensive approach: development of varieties of crops, development of rainfall and temperature tolerant plants, and finding alternative crops and hybrids.

- To find alternative approach: changing crop cycle and reducing the timing of crop cycle.

- To provide information: providing weather forecast and early warning system and ensuring delivery of proper information at the farm level.

The impacts of climate change on agricultural sustainability vary from country to country, region to region and time to time. The yield and productivity of agricultural crops in Malaysia are proven to have been heavily influenced by climatic variations. Malaysia is the $26^{\text {th }}$ largest greenhouse gas emitter which causes the expected rise of temperature by $0.3^{\circ} \mathrm{C}$ to $4.5^{\circ} \mathrm{C}$, and rise in sea level is expected to be about $95 \mathrm{~cm}$ over the time span of one hundred years. The changes in the country's rainfall fluctuate heavily from $-30 \%$ to $+30 \%$. This change reduces crop yield and is prone to drought in many areas so that cultivation of some crops such as rubber, oil palm and cocoa becomes unfeasible. Current crop productivity is also affected by the climatic variations throughout the country as the actual farm yields of rice in Malaysia vary from 3-5 tons per hectare while the potential yield is 7.2 tons per hectare. The projection of climate change and its impacts on productivity and farmers' profitability are thus considered very alarming.

\section{ACKNOWLEDGEMENT}

We are thankful to Ministry of Science, Technology and Environment of the Government of Malaysia for generously funding the research, under the Research University Grants (UKMAP-PLW-04-2010, LRGS-TD-2011-UPM-UKM-KM-04 and UKM-GUP-PI-08-34-081). We would also like to thank Dr. Basri Talib, Dr. Mohd Ekhwan bin Toriman, Prof Dr. Abdul Hamid Jaafar (National University of Malaysia), Md. Wahid Murad (University of Adelaide, Australia), and Prof. Dr. Rafiqul Islam Molla (Multimedia University, Malaysia) for their advices and supports at various stages of the study.

\section{REFERENCES}

Agriculture Statistical Handbook, 2008. Paddy. Ministry of agriculture. Malaysia. Alam M.M., Siwar C., and Al-Amin A.Q. 2010b. Climate Change Adaptation Policy Guidelines for Agricultural Sector in Malaysia. Asian Journal of Environmental and 
Disaster Management 2(4):463- 469. DOI 10.3850/S1793924011000873 Cited 05 Nov 2012

Alam M.M., Siwar C., Molla R.I., Toriman M.E., and Talib B. 2011b. Climate Change and Vulnerability of Paddy Cultivation in North-West Selangor, Malaysia: A Survey of Farmers' Assessment. Voice of Academia 6(1):45-56.

Alam M.M., Talib B., Siwar C., and Toriman M.E. 2010a. The Impacts of Climate Change on Paddy Production in Malaysia: Case of Paddy Farming in North-West Selangor. Proceedings of the international conference of the 4th International MalaysiaThailand Conference on South Asian Studies. National University of Malaysia, Malaysia, Mar 25-26.

Alam M.M., Toriman M.E., Siwar C., and Talib B. 2011a. Rainfall variation and changing pattern of agricultural cycle. American Journal of Environmental Science 7:82-89. DOI 10.3844/ajessp.2011.82.89 Cited 05 Nov 2012

Alam M.M., Toriman M.E., Siwar C., Molla R.I., and Talib B. 2011c. The Impacts of Agricultural Supports for Climate Change Adaptation: Farm Level Assessment Study on Paddy Farmers. American Journal of Environmental Sciences 7(2): 178-182. DOI 10.3844/ajessp.2011.82.89 Cited 05 Nov 2012

Alam, M.M., Siwar C., Murad M.W., and Toriman M.E. 2011d. Impacts of Climate Change on Agriculture and Food Security Issues in Malaysia: An Empirical Study on Farm Level Assessment. World Applied Sciences Journal 14(3): 431-442. http://idosi.org/wasj/wasj14(3)11/12.pdf Cited 05 Nov 2012

Alam, M.M., Siwar, C., Mohd Ekhwan, T., Molla, R.I., and Talib, B. 2012a. Climate Change Induced Adaptation by Paddy Farmers in Malaysia, Mitigation and Adaptation Strategies for Global Change 17(2): 173-186. http://www.springerlink.com/content/w443477600871315/ Cited 05 Nov 2012

Alam, M.M., Siwar, C., Molla, R.I., Talib, B., and Mohd Ekhwan, T. 2012d. Paddy Farmers' Adaptation Practices to Climatic Vulnerabilities in Malaysia, Mitigation and Adaptation Strategies for Global Change 17(4): 415-423. http://www.springerlink.com/content/31427ppr79181715/ Cited 05 Nov 2012

Alam, M.M., Siwar, C., Talib, B., Jaafar, A.H., and Mohd Ekhwan, T. 2012c. Farmers' Perceptions Study on Required Supports for Climate Change Adaptation in Malaysia, Asian Journal of Environmental and Disaster Management 4(1): 83-97. http://www.rpsonline.com.sg/journals/101ajedm/2012/0401/S179392402012001081.php Cited 05 Nov 2012

Alam, M.M., Siwar, C., Talib, B., Mokhtar, M., and Mohd Ekhwan, T. 2012b. Climate Change Adaptation Policy in Malaysia: Issues for Agricultural Sector, African Journal of Agricultural Research 7(9): 1368-1373. http://www.academicjournals.org/ajar/PDF/pdf2012/5\%20Mar/Alam\%20et\%20al.pdf Cited 05 Nov 2012

Baker, J. T. and Allen, Jr. L. H. 1993. Contrasting crop species responses to $\mathrm{CO}_{2}$ and temperature: rice, soybean and citrus. Vegetatio 104/105: 239-260.

Behringer, J., Buerki, R., and Fuhrer, J. 2000. Participatory integrated assessment of adaptation to climate change in Alpine tourism and mountain agriculture, Integrated Assessment 1: 331-338.

Boko, M., Niang, I., Nyong, A., Vogel, C., Githeko, A., Medany, M., Osman-Elasha, B., Tabo, R. and Yanda, P. 2007. 'Africa' in Climate Change 2007: Impacts, Adaptation and Vulnerability. Contribution of Working Group II to the Fourth Assessment Report of the Intergovernmental Panel on Climate Change, M.L. Parry, O.F. Canziani, J.P. 
Palutikof, P.J. Van der Linden and C.E. Hanson (eds) Cambridge University Press: Cambridge UK.

Bonaccorso, B., Cancelliere, A. and Rossi, G., 2005. Detecting trends of extreme rainfall series in Sicily. Advances in Geosciences 2: 7-11.

Brown, K., Few, R. and Tompkins, E. L. 2007. Climate change and coastal management decisions: insights from Christchurch Bay, Coastal Management 35(2-3): 255-270.

Brunetti, M., Buffoni, L., Maugeri, M. and Nanni, T., 2000. Precipitation intensity trends in Northern Italy. International Journal of Climatology 20: 1017-1031.

Brunetti, M., Colacino, M., Maugeri, M. and Nanni, T. 2001. Trends in the daily intensity of precipitation in Italy from 1951 to 1996. International Journal of Climatology 21: 299-316.

Commission of the European Communities. 2007. Green Paper from the Commission to the Council, the European Parliament, the European Economic and Social Committee and the Committee of the Regions: Adapting to climate change in Europe - options for EU action, COM (2007) 354 final, Official Journal C 120 , 16/05/2008 P. 0038 0041. Brussels.

Curb Global Warming. 2007. Malaysia Leads the World in Greenhouse Gas Emission Growth Rate. http://curbglobalwarmingblog.blogspot.com/2007/11/malaysia-leadsworld-in-greenhouse-gas.html Cited 05 Aug 2011

Daly, H., and Cobb, J. 1990. For the Common Good, Green Print Publishing: London.

Eisenack, K. and Kropp, J. 2006. Regional Stakeholder Perceptions of Climate Change: Baltic Case Study Screening, ASTRA document, Potsdam.

Eisenack, K., Tekken, V. and Kropp, J. 2007. Stakeholder Perceptions of Climate Change in the Baltic Sea Region, Coastline Reports 8:245-255.

Fuhrer, J., Beniston, M., Fischlin, A., et al. 2006. Climate risks and their impact on agriculture and forests in Switzerland. Climatic Change 79: 79-102.

WBGU. 2003. Climate Change - Strategies for the 21 century: Kyoto and beyond, German Advisory Council on Global Change (Eds.), Berlin. http://www.wbgu.de/wbgu_sn2003_engl.pdf, 08.11.2006 Cited 05 Aug 2011

Groisman, P. Ya., Karl, T.R., Easterling, D. R., Knight, R. W., Jamason, P. F., Hennessy, K. J., Suppiah, R., Page, C. M., Wibig, J., Fortuniak, K., Razuvaev, V. N., Douglas, A., Forland, E. J. and Zhai, P. 1999. Changes in the probability of heavy precipitation: important indicators of climatic change. Climate Change 42: 243-283.

Homer-Dixon, T. 1992. Environment al Change and Acute Conflict, International Security 16 (2): 31-102.

Houghton, J. T., Filho, L. G. M., Callander, B.A., Harris, N., Kattenberg, A. and Maskell, K. (Eds.), 1996. Climate Change, "The IPCC Second Assessment Report". Cambridge University Press: New York.

IPCC (Intergovernmental Panel on Climate Change). 2001. Climate Change 2001: The Scientific Basis, Houghton, JT, Ding, Y., Griggs, D.J. et aI., Eds., Cambridge University Press, Cambridge, U.K.

IPCC (Intergovernmental Panel on Climate Change). 2007. Climate Change 2007: The Physical Science Basis, Intergovernmental Panel on Climate Change, Cambridge University Press, Cambridge.

Karl, T. R., Knight, R.W. and Plummer, N. 1995. Trends in high-frequency climate variability in the twentieth century. Nature 377: 217-220.

Klein, R. J. T., Schipper, E. L. F. and Dessai, S. 2005. Integrating mitigation and adaptation into climate and development policy: three research questions. Environmental Science and Policy 8(6): 579-588. 
Kunkel, K. E., Pielker Jr., R. A. and Changnon, S.A., 1999. Temporal fluctuation in winter and climate extremes that cause economic and human health impact: a review. International Journal of Climatology 19: 1077-1098.

Lobell, D.B., Burke, M. B., Tebaldi, C., Mastrandrea, M. D., Falcon, W. P. and Naylor, R. L. 2008. Prioritizing climate change adaptation needs for food security in 2030, Science 319(5863): 607-610.

Mason, S. J., Waylen, P. R., Mimmack, G. M., Rajaratnam, B. and Harrison, J. M., 1999. Changes in extreme rainfall events in South Africa. Climate Change 41: 249-257.

Matthews, R. B. et al. 1994a. Climate Change and Rice Production in Asia, Entwicklung und Landlicherraum 1: 16-19.

Matthews, R. B. et al. 1994b. "The Impact of Global Climate Change on Rice Production in Asia: a Simulation Study”. Report No. ERL-COR-821. Corvallis, OR: U.S. Environmental Protection Agency, Environmental Research Laboratory.

MOSTE, 2001. National Response Strategies to Climate Change. Ministry of Science, Technology and the Environment, Putrajaya, Malaysia.

Muller, M. 2007. Adapting to climate change: water management for urban resilience Environment and Urbanization 19(1): 99-113.

NAHRIM. 2006. "Final Report: Study of the Impact of Climate Change on the hydrologic Regime and Water Resources of Peninsular Malaysia", National Hydraulic Research Institute of Malaysia (NAHRIM) and California Hydrologic Research Laboratory (CHRL).

National Academy of Science. 2001. Climate change science: An analysis of some key questions, Committee on the Science of Climate Change, National Academy Press, Washington, D.C.

Osborn, T. J., Hulme, M., Jones, P. D. and Basnett, T. A. 2000. Observed trends in the daily intensity of United Kingdom precipitation. International Journal of Climatology 20: 347-364.

Pielke, R., Prins. G., Rayner S. and Sarewitz, D. 2007. Lifting the taboo on adaptation. Nature 445(7128): 597-598.

Plummer, N. J., Salinger, A., Nicholls, N., Suppiah, R., Hennessy, K., Leighton, R. M., Trewin, B., Page, C. M. and Lough, J. M., 1999. Changes in climate extremes over the Australian region and New Zealand during the twentieth century. Climate Change 42: 183-202.

Raworth, K. 2007. Adapting to climate justice: What's needed and who should pay for climate adaptation in developing countries. Oxfam, Oxford.

Reilly, J. 1999. Climate Change: Can Agriculture Adapt?, Choices 14(1): 4-8.

Schimmelpfenning, D. 1996. Uncertainty in Economic Models of Climate Change Impacts. Climatic Change 33(2): 213-34.

Singh, S., Amartalingam, R., Wan Harun, W.S. and Islam, M.T. 1996. Simulated impact of climate change on rice production in Peninsular Malaysia, Proceeding of National Conference on Climate Change. UPM, pp. 41-49.

Siwar C, Alam MM, Murad MW, and Al-amin AQ (2009) A review of the linkages between climate change, agricultural sustainability and poverty in Malaysia. International Review of Business Research Papers 5(6):309-321. http://www.bizresearchpapers.com/23.\%20Siwar.pdf Cited 05 Nov 2012

Smit, B. and Skinner, M. W. 2002. Adaptation Options in Agriculture to Climate Change: A Typology. Mitigation and Adaptation Strategies for Global Change 7: 85-114.

Stern, N. 2007. The Economics of Climate Change: The Stern Review. Cambridge University Press, Cambridge. 
Suppiah, R. and Hennessey, K. J., 1998. Trends in total rainfall, heavy rain events and numbers of dry days in Australia. International Journal of Climatology 18: 11411164.

Tashiro, T., and Wardlaw, I. F. 1989. A comparison of the effect of high temperature on grain development in wheat and rice, Annals of Botany 64: 59-65.

Tisdell, C. 1996. Economic indicators to assess the sustainability of conservation farming projects: An evaluation Agriculture, Ecosystems and Environment 57(2): 117-131.

Trenberth, K. E., 1998. Atmospheric moisture residence times and cycling: implications for rainfall rates with climate change. Climate Change 39: 667-694.

United Nations. 1997. Critical Trends: Global Changes and Sustainable Development, UN Department for Policy Coordination and Sustainable Development, New York.

Webster, M. et al. 2002. "Uncertainty Analysis of Climate Change and Policy Response." Report no. 95. Cambridge, Mass.: Massachusetts Institute of Technology Joint Program on the Science and Policy of Global Change. December.

Zwiers, F. W. 2002. Climate Change: The 20-Year Forecast, Nature 416: 690-691. 